\title{
Exploitation of IAA Producing PGPR on mustard (Brassica nigra L.) seedling growth under cadmium stress condition in comparison with exogenous IAA application
}

\author{
Amit Kumar Pal, Sutapa Mandal and Chandan Sengupta* \\ Microbiology Research Laboratory, Department of Botany, University of Kalyani, Kalyani 741235, West Bengal, India
}

\section{Article history}

Received: 26 October 2018 Accepted: 05 January 2019 Published: 12 January 2019

\section{Editor}

Dr Veena S Anil

University of Agricultural Sciences, Bangalore

India

\section{Publisher}

Horizon e-Publishing Group

\author{
*Correspondence \\ Chandan Sengupta \\ $\triangle$ chandansenguptaku@gmail.com
}

\begin{abstract}
Soil pollution by cadmium (Cd) is a global threat for plants and animals. Exogenous auxin application reduces the $\mathrm{Cd}$ stress on plants. Moreover, IAA production by rhizospheric bacteria can play a key role in plant growth and development by promoting cell division, cell elongation, cell differentiation, flowering and lateral root formation. The present study was to evaluate the efficiency of IAA producing, Cd tolerant plant growth promoting rhizobacteria for plant (Brassica nigra L.) growth under Cd stressed condition comparing with the external synthetic auxin application. Lysinibacillus varians and Pseudomonas putida were isolated previously as IAA producing PGPR and selected in this study for their exploitation in plant growth development under Cd stressed condition. The impact of external synthetic IAA application significantly increased the plant growth under $\mathrm{Cd}$ amended soil. Whereas, PGPR inoculation also showed significant $(p<0.05)$ elevation in germination percentage, root and shoot length, chlorophyll content and other growth parameters of Cd stressed Brassica plants which were comparative to synthetic IAA application. So, these selected PGPRs (L. varians and P. putida) can be used as biofertilizer which ameliorate the adverse effect of cadmium.
\end{abstract}

Keywords: Cadmium stress; IAA; plant growth promoting rhizobacteria; plant growth.

\section{Citation}

Pal AK, Mandal S, Sengupta C. Exploitation of IAA Producing PGPR on mustard (Brassica nigra L.) seedling growth under cadmium stress condition in comparison with exogenous IAA application. Plant Science Today 2019;6(1):22-30. https://doi.org/10.14719/pst.2019.6.1.440

Copyright: (c) Pal et al. (2019). This is an open-access article distributed under the terms of the Creative Commons Attribution License, which permits unrestricted use, distribution, and reproduction in any medium, provided the original author and source are credited (https://creativecommons.org/licenses/by/4.0/).

Indexing: Plant Science Today is covered by Scopus, CAS, AGRIS, CABI, Google Scholar, etc. Full list at http://www.plantsciencetoday.online

\section{Introduction}

The world population is increasing day by day. Agricultural production has increased by the use of high yielding varieties along with chemical fertilizers and pesticides application. The pursuit for producing more crop yield by excessive use of chemicals cause deterioration effects in the chemical, physical and biological health of cultivable land (1). So, the futuristic agricultural development is absolutely important for the sustainable advances (2). Moreover, soil pollution by different heavy metals is one of the major threats for agricultural development. The primary source of soil pollution includes the accumulation of heavy metals through emissions from the rapidly expanding industrial areas, disposal of high metal wastes, metal forging, spillage of petrochemicals, application of fertilizers, sewage sludge application, 
pesticides, wastewater irrigation in agronomic practices (3). Though these sewage effluents are a good source of organic matter with other nutrients but also they elevate different heavy metals like $\mathrm{Fe}, \mathrm{Mn}, \mathrm{Cu}, \mathrm{Zn}, \mathrm{Pb}, \mathrm{Cr}, \mathrm{Ni}, \mathrm{Cd}$ and $\mathrm{Co}(4,5)$. Heavy metals can found on the surface and in the tissue of fresh vegetables. Prolonged consumption of unsafe concentrations of heavy metals in foodstuffs may cause the disruption of numerous biological and biochemical processes in the human body.

Cadmium slows down the plant growth by inhibiting many enzymes, involved in respiration and photosynthesis $(6,7)$. Cadmium stresses also inhibits the germination percentage, root or shoot development and other plant growth parameters $(8,9)$. Yoan and Huang showed that Cd increased the nitric oxide (NO) accumulation in the root, which hold back the transport of auxin by inhibiting PIN1 protein activity. Inhibited PIN1 protein reduces the root apex auxin concentration resulting reduced root meristem size (10). PINFORMED1 (PIN1) protein is an auxin efflux carrier, involved in the maintenance of the root meristem growth (11). Moreover, PIN1 was also reported as a key protein involved in the auxin circulation under heavy metal stress condition (12).

Cadmium stress decrease the endogenous level of auxin by disturbing the IAA homeostasis in the root tips (13) that suppress the primary root elongation (14). Exogenous application of auxin or its precursor L-TRP can increase the endogenous levels of auxins which ultimately enhanced the plant growth and yield under Cd stress (15). So, external application of auxin reduces the $C d$ stress on plants. Furthermore, IAA producing plant growth promoting rhizobacteria (PGPR) can be an attractive alternative for replacing the synthetic auxin application to reduce the Cd stress and to decrease the use of chemical fertilizers for reclamation of environmental pollution (9). Cd tolerant PGPR can maintain the soil fertility in $\mathrm{Cd}$ contaminated soil by different direct or indirect mechanism such as to solubilise insoluble phosphate or potassium, nitrogen fixation, siderophore production, ammonium production, phytohormone such as IAA production etc $(8,9,16)$.

The objective of the study was to determine the effectiveness of IAA producing PGPR strains in comparison with the external synthetic auxin application for the plant growth and development under Cd stress condition.

\section{Materials and Methods}

\section{Collection of Bacteria}

Two potent cadmium tolerant plant growth promoting rhizobacteria were isolated previously by standard microbiological techniques. These bacteria were already characterized and identified as Lysinibacillus varians (NCBI GenBank accession number MG976681) and Pseudomonas putida (NCBI GenBank accession number MG976684) for further research work.

\section{Characterization of Bacteria}

The collected Cd resistant PGPR isolates were previously characterized by morphological and biochemical properties such as amylase, Catalase, methyl red, citrate utilization, gelatine hydrolysis, indole production, urease with standard protocol (9).

Plant growth promoting ability of the bacterial isolates was determined such as IAA production (17), Phosphate solubilization (18), ammonia production (19), HCN production (20), Nitrogen-fixing ability (21) and siderophore production (22).

Exploitation of PGPR on growth and development of mustard (Brassica nigra L.) seedlings in heavy metal (Cd) stress condition

\section{Collection of seed}

Mustard (Brassica nigra L.) was used as test plant in this experiment. Seeds were collected from Bidhan Chandra Krishi Viswavidyalaya, W.B.

\section{Dose determination}

Initially mustard seeds were treated with different concentration of $\mathrm{Cd}(5,10,20,40,80,160,320,640$ $\mathrm{ppm}$ ) for dose determination of the seeds. The concentration of $\mathrm{Cd}$, at which the growth of seedling was affected to some extent but not too much leading to death (i.e. $10 \mathrm{ppm}$ of $\mathrm{Cd}$ ), was taken for consideration in this study. In the second set of experiments different IAA concentrations $(0$, $10^{-8}, 10^{-7}, 10^{-6}, 10^{-5} \mathrm{M}$ ) were applied from the germination state to seedling state of Brassica. On the basis of effective seedling growth, $10^{-6} \mathrm{M}$ of IAA was determined for further experiments.

\section{Seed germination test}

The Mustard seeds were surface sterilized/ disinfected to avoid the presence of any pathogenic microorganisms on the seed surface by dipping the seeds for 3 minutes in $0.1 \% \mathrm{HgCl}_{2}$ and washing 4 times in sterilized water. Initially bacterial cultures were prepared in NA slant. 48 hrs old fresh cultures was scrapped with sterile inoculating needle and suspended in sterile distilled water. Seeds were then inoculated with water suspension of bacterial culture $\& 10^{6}$ cells/ml). After $10 \mathrm{hrs}$ of inoculation the seeds were placed on the sterile blotting paper in different experimental setups. Number of seed germination was recorded after $24 \mathrm{hrs}$ intervals up to 6 days. The different experimental setups are as follows:

$\begin{array}{ll}\text { - } & \text { Control } \\ \text { - } & \text { IAA (10-6M) } \\ \text { - } & \text { Cd+IAA } \\ \text { - } & \text { Cd+A } \\ \text { - } & \text { Cd+T }\end{array}$

- Control

- Cadmium (10ppm)

- $\quad$ Cd+IAA

- $\mathrm{Cd}+\mathrm{T}$ 
Table 1. Colony morphology, Gram nature, Biochemical characterization and PGP ability of the Bacterial isolates

\begin{tabular}{|c|c|c|c|c|}
\hline $\begin{array}{l}\text { Bacterial } \\
\text { isolates }\end{array}$ & $\begin{array}{l}\text { Minimal Inhibitory } \\
\text { Concentration of } \\
\text { Cadmium }\end{array}$ & $\begin{array}{c}\text { Colony } \\
\text { Morphology \& Gram } \\
\text { nature }\end{array}$ & Biochemical characterization & $\begin{array}{c}\text { Plant growth promoting } \\
\text { ability }\end{array}$ \\
\hline $\begin{array}{c}\mathrm{A} \\
\text { (L. varians) }\end{array}$ & $150 \mathrm{ppm}$ & $\begin{array}{l}\text { Creamy yellow, circular } \\
\text { with serrated margins, } \\
\text { opaque with a glossy } \\
\text { surface, Gram-positive, } \\
\text { rod }\end{array}$ & $\begin{array}{l}\text { Catalase, methyl red, citrate } \\
\text { utilization tests positive and } \\
\text { amylase, gelatin hydrolysis, indole } \\
\text { production, urease tests negative }\end{array}$ & $\begin{array}{l}\text { ammonia production, IAA } \\
\text { production }(20.43 \pm 0.318 \mu \mathrm{g} \\
\text { ml), Nitrogen-fixing ability, } \\
\text { low phosphate solubilization } \\
\text { and low siderophore } \\
\text { production positive }\end{array}$ \\
\hline $\begin{array}{c}\mathrm{T} \\
\text { (P.putida) }\end{array}$ & $150 \mathrm{ppm}$ & $\begin{array}{l}\text { Creamy white, circular } \\
\text { entire margin with a } \\
\text { glossy surface, Gram- } \\
\text { negative rod }\end{array}$ & $\begin{array}{l}\text { Catalase, methyl red, citrate } \\
\text { utilization positive and amylase, } \\
\text { gelatine hydrolysis indole } \\
\text { production, urease test negative }\end{array}$ & $\begin{array}{l}\text { phosphate solubilisation, } \\
\text { ammonia production, IAA } \\
\text { production }(20.05 \pm 0.266 \mu \mathrm{g} \\
\text { ml), low siderophore } \\
\text { production }\end{array}$ \\
\hline
\end{tabular}

NB: $\quad \mathrm{Cd}=10 \quad$ ppm, $\quad \mathrm{IAA}=10^{-6} \mathrm{M}, \quad \mathrm{A}=$ Lysinibacillus varians and $\mathrm{T}=$ Pseudomonas putida

Germination percentage were calculated by the following formula:

Germination percentage $=$ (Total no of germinated seeds / Total no of seeds) x 100

\section{Pot Experiments}

For exploitation of PGPR, pots were prepared with sterile sleeved soil and sand as one third depth of pot were filled with sterile sand and upper remaining portion were filled with fine sterile soil. Imbibed seeds were shown in the different experimental set up as described earlier, but in case of bacterial inoculation Brassica seeds were imbibed in the water suspension of selected bacteria separately. All the experimental setups were triplicated and continuously altered their position for elimination of position effect.

\section{Growth parameters}

Up to 75 days of seedling development, different growth parameters such as shoot length (cm), root length $(\mathrm{cm})$, number of leaves, leaf area $\left(\mathrm{cm}^{2}\right)$, inflorescence length $(\mathrm{cm})$, fresh weight $(\mathrm{mg})$, dry weight (mg), seed weight (mg), chlorophyll content ( $\mathrm{mg} / \mathrm{gm}$ of tissue), vigour index $(\mathrm{cm})$ and relative water content were recorded.

\section{Estimation of chlorophyll}

$0.5 \mathrm{~g}$ of each plant material was taken in the test tubes containing $10 \mathrm{ml}$ of methanol and kept in dark (23). After $24 \mathrm{hrs,} \mathrm{the} \mathrm{supernatant} \mathrm{solution}$ from each test tube was taken for measurement of absorbance at 470, 652 and $665 \mathrm{~nm}$ [A470, A652 and A665] by the help of Spectrophotometer (Microprocessor visible, model no-LI-722, Lasany, Made in India).

Chl a $(\mathrm{mg} / \mathrm{gm}$ tissue $)=16.29 \times \mathrm{A} 665-8.54 \times \mathrm{A} 652$

$\mathrm{Chl} \mathrm{b}(\mathrm{mg} / \mathrm{gm}$ tissue $)=30.66 \times \mathrm{A} 652-13.58 \times \mathrm{A} 665$

$\mathrm{Chl} \mathrm{a}+\mathrm{b}(\mathrm{mg} / \mathrm{gm}$ tissue $)=22.12 \times \mathrm{A} 652+2.71 \times \mathrm{A} 665$

\section{Vigour index}

Vigour index was calculated using the following formula suggested by Abdul-Baki and Anderson (24) and expressed as whole number.

$$
\begin{aligned}
& \text { Vigour index }=\text { Germination (\%) } \mathrm{x} \text { Total } \\
& \text { seedling length }(\mathrm{cm})
\end{aligned}
$$

\section{Relative Water Content}

RWC was calculated using the following formula

RWC $(\%)=(F W-D W / T W-D W) \times 100$.

Where, FW = Fresh weight

DW $=$ Dry weight

TW $=$ Turgid weight.

\section{Statistical analysis}

Standard error (SE) of all experiments was intended from triplicates $(n=3)$ and represented in the Table (value \pm SE) and figures (error bar). Variations within the experimental groups were considered unpaired t-test. Difference in between control and cadmium treated groups are denoted by lower case alphabet ' $a$ '. Whereas, lower case alphabet ' $b$ ' denotes the differences between $\mathrm{Cd}$ treated groups and respective other groups. Asterisk (*) above the bars indicate significant level.

\section{Results and Discussion}

IAA is one of the major phytohormone which can be produced by many rhizobacteria. In this study two potent PGPR were selected as potential IAA producers. L. varians and P. putida both produced approximately $20 \mathrm{ppm}$ of IAA along with other plant growth promoting abilities (Table 1).

\section{Effect on plant growth}

Cadmium application adversely affected the seed germination (Fig. 1). But it was rather improved with the exogenous IAA application by 1.09 fold. 
Table 2. Plant growth parameters in different experimental setups

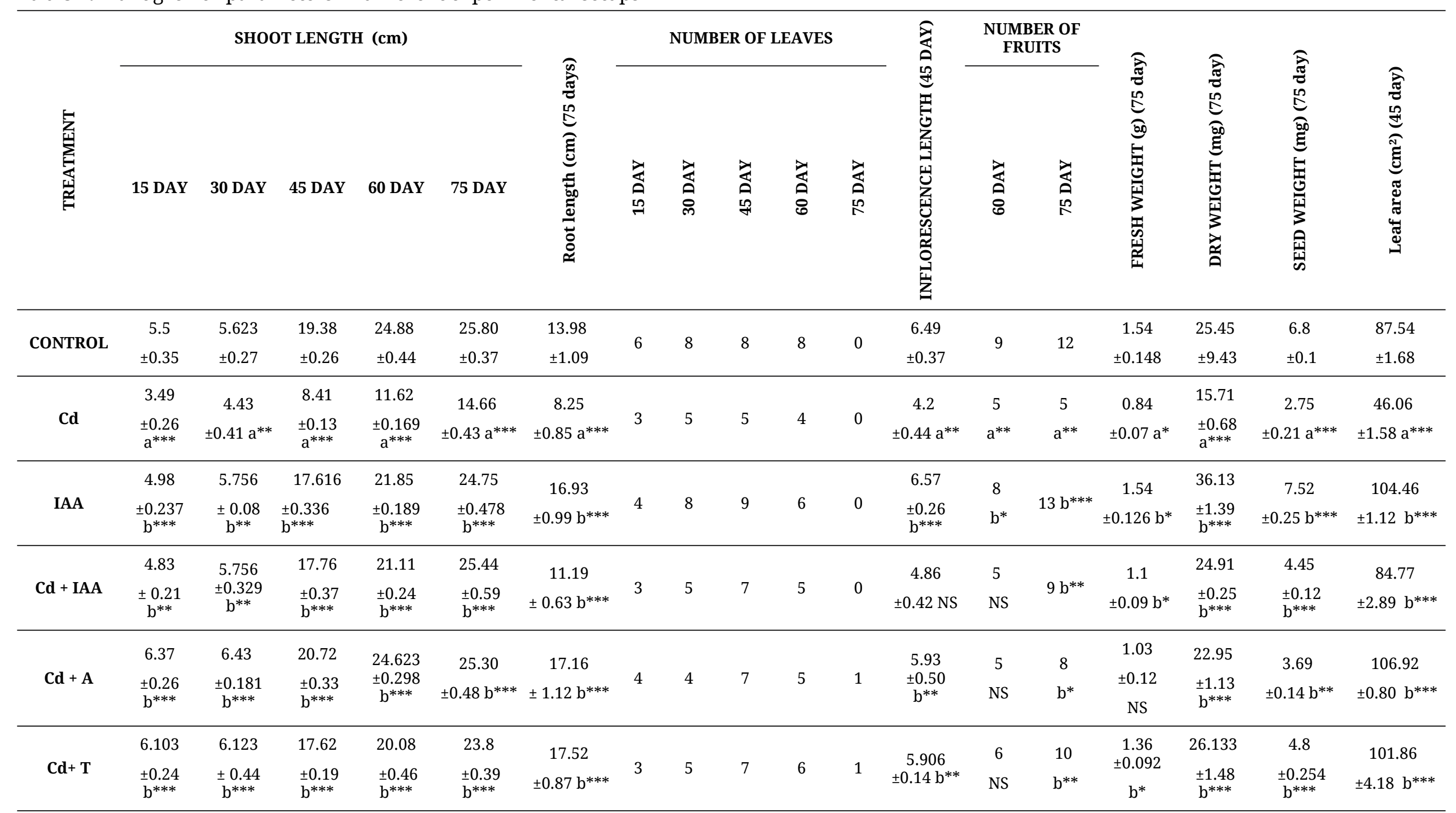

Difference in between control and cadmium treated groups are denoted by lower case alphabet 'a'. Whereas, lower case alphabet 'b' denotes the differences between $\mathrm{Cd}$ treated groups and respective other groups. Asterisk $\left(^{*}\right)$ indicates significant level (A- L. varians, B- P. putida). 


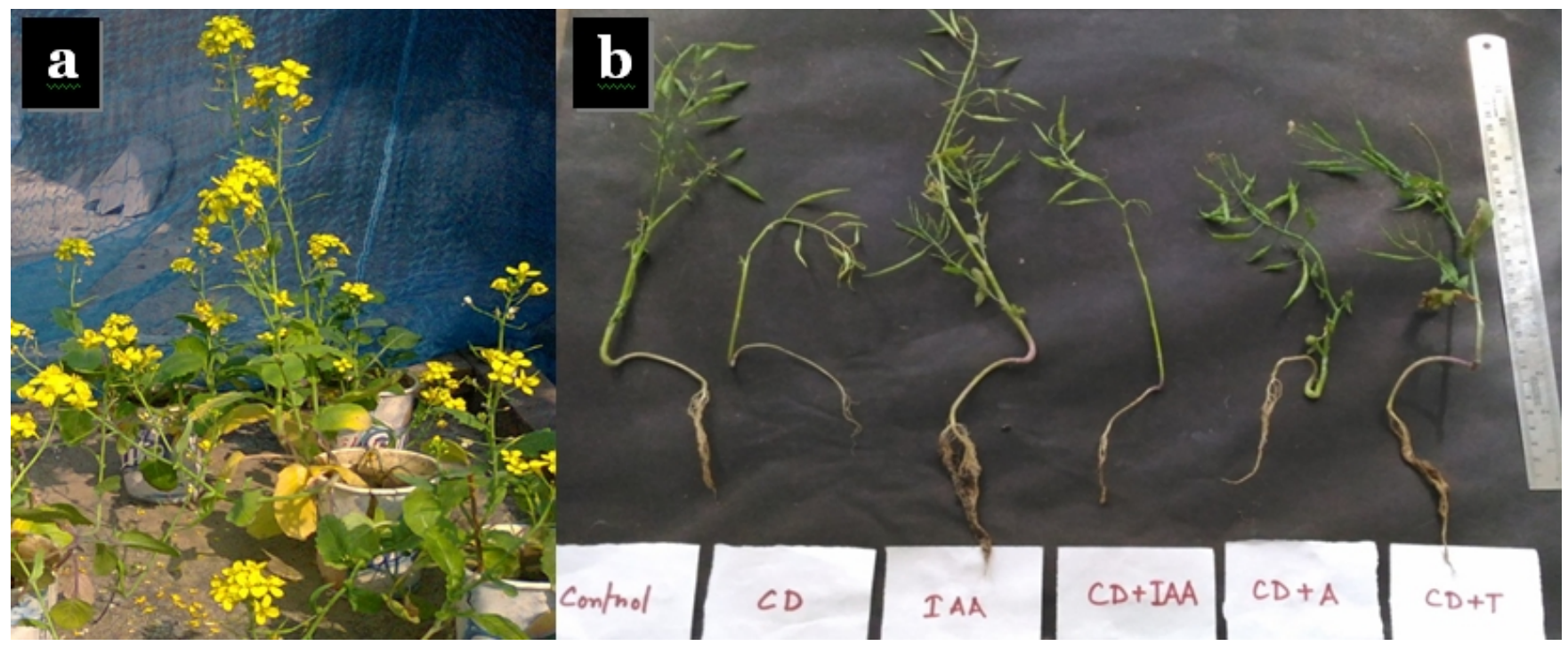

Photograph 1. Shoot \& root length measurement of brassica plant (b). (a- experimental set) (A- L. varians, B- P. putida)
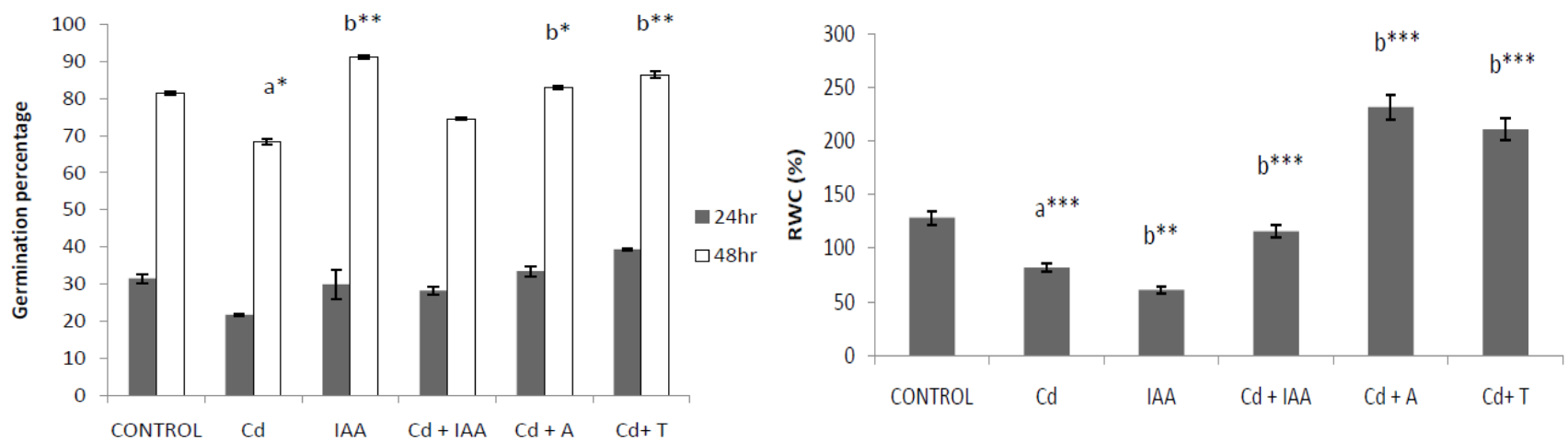

Fig. 1. Seed germination under $C d$ stress condition

Fig. 2. RWC (\%) under Cd stress condition

Difference in between control and cadmium treated groups are denoted by lower case alphabet 'a'. Whereas, lower case alphabet ' $b$ ' denotes the differences between Cd treated groups and respective other groups. Asterisk $\left({ }^{*}\right)$ above the bars indicate significant level. (A- L. varians, B- P. putida).

Difference in between control and cadmium treated groups are denoted by lower case alphabet ' $a$ '. Whereas, lower case alphabet ' $b$ ' denotes the differences between $\mathrm{Cd}$ treated groups and respective other groups. Asterisk $(*)$ above the bars indicate significant level. (A- L. varians, $B$ - P. putida).

Whereas, PGPR mediated seed germination was also increased under $\mathrm{Cd}$ stressed condition by 1.21 and 1.26 fold respectively for $L$. varians and $P$. putida inoculation. It was previously reported that $\mathrm{Cd}$ stress decreased seed germination of different crops $(8,9,25,26)$. It was important to note that the PGPR isolates have some positive effects on seed germination. So, this study indicates that PGPR can safely use for enhancement of seed germination in heavy metal contaminated soils.

Application of $\mathrm{Cd}$ in the soil system reduced the plant growth than the control plant (Table 2; Photograph 1). Application of synthetic auxin significantly $(p<0.05)$ increased the shoot length and root length under cadmium stressed soil than the heavy metal stressed condition alone. Both the selected IAA producing PGPRs showed somewhat similar kind of growth enhancement like that of exogenous auxin application under $\mathrm{Cd}$ stress. Inoculation of $L$. varians and $P$. putida certainly reduced the adverse effects of Cd stress. It was previously reported that the bad effects of $\mathrm{Cd}$ become more severe with the increased heavy metal concentration (26). Aydinalp and Marinova also showed that $20 \mathrm{ppm}$ of $\mathrm{Cd}$ reduced the alfalfa shoot length by $62 \%$ (26). In our study shoot length and root length of mustard was decreased by $43.18 \%$ and $40.99 \%$ with $\mathrm{Cd}$ application respectively. Whereas, L. varians and P. putida increased shoot length by 1.73 and 1.62 fold or root length by 2.08 and 2.12 fold correspondingly than the un-inoculated $\mathrm{Cd}$ stressed plants (Photograph 1). Similar type of PGPR mediated plant growth enhancement under Cd stress was noticed by different researchers $(8,9,27)$. Literature revealed that $\mathrm{Cd}$ inhibited PIN1 protein activity which decreased the root meristem by reducing auxin concentration (10). Exogenous synthetic auxin or PGPR mediated IAA application can help the plant growth under Cd stress even though, the internal auxin concentration of plant was low.

Average number of leaves was increased slightly with the inoculation of PGPR it was not significantly altered in all the cases, but leaf area significantly $(p<0.05)$ increased with the PGPR 
application. L. varians and P. putida enhanced the leaf area by 2.29 and 2.18 fold respectively under $\mathrm{Cd}$ amended condition (Table 2). This study revealed that Cd-stress on mustard plant was somehow reduced by $L$. varians and $P$. putida for the leaf development. Synthetic auxin application abridged the $\mathrm{Cd}$ stress and improved the inflorescent length by 1.16 fold than the only $\mathrm{Cd}$ treated plants. On the other hand, L. varians and $P$. putida, under $\mathrm{Cd}$ contamination, improved the length of inflorescence by 1.41 and 1.4 fold as compared to $\mathrm{Cd}$ stressed condition. Simultaneously, fruit number was also increased with the application of synthetic IAA (1.8 fold) or by any of the PGPR under Cd stress (Table 2). $L$. varians and $P$. putida increased the number of fruits by 1.8 and 2 fold accordingly under heavy metal amended condition. Great increment was noticed in case of IAA application for the seed weight production. IAA application, $L$. varians and $P$. putida inoculation lessen the heavy metal stress and helped the plant to increase the seed weight by $1.61,1.34$ and 1.74 fold correspondingly. Fruit development and number of seed in mustard plant is proportionately dependent on the inflorescence length and flower number. So, it was evident from this study that PGPR application helped to increase productivity of mustard. Cd contamination drastically $(p<0.05)$ reduced fresh weight as well as dry weight by 45.45 and $38.11 \%$ than the control plants (Table 2). In case of fresh weight or dry weight, $L$. varians and $P$. putida produced better performance than the un-inoculated Cd stress. IAA producing $L$. varians and $P$. putida enhanced these growth parameters significantly $(p<0.05)$ which were comparable to synthetic IAA application.

It was previously reported by $\mathrm{Pal}$ et al. that L. varians and P. putida enhanced different plant growth parameters of chilli plant such as germination percentage, root length, shoot length, number of leaves, leaf area, fresh weight, dry weight and chlorophyll content under $\mathrm{Cd}$ or $\mathrm{Pb}$ stressed condition (9). Rajkumar and Freitas observed that Pseudomonas and Arthrobacter produce IAA that helped for better growth and development (27). PGPR increases dry weight under heavy metal stress condition (28). The increased plant biomass is due to production of different phytohormones like Gibberellins, IAA etc (27). According to Aydinalp and Marinova (26), under increasing Cd stress, root length and shoot length were gradually decreased. It was previously reported that $\mathrm{Cd}$ damages many plants by Cd-ROSMAP kinase signal which was diminished by IAA producing PGPR to enhance the rice seedling growth under Cd stress (29). PGPR-produced IAA enhanced plant growth by increasing nutrient uptake with accelerated root growth under $\mathrm{Cd}$ stressed condition $(30,31)$. Pishchik et al. reported $\mathrm{Cd}$ tolerant Klebsiella mobilis decreased Cd content and increased grain yield in barley (32). Abbass and Okon suggested that IAA and other plant hormones could be responsible for improved growth of canola, tomato, and wheat inoculated with Azotobacter paspali (33). Similar type of observation was made recently by Kamran et al in case of Eruca sativa, where inoculation of bacteria facilitated to overcome the adverse effect of heavy metal (28). Cd inhibits root elongation by accumulation nitric oxide (NO) in root meristem suppressing PIN 1 protein (10). Cd hampers root endogenous auxin concentration by inhibiting PINFORMED1 (PIN1), which act as an auxin efflux protein $(13,11)$. According to Farooq et al., exogenous auxin application enhanced plant growth under Cd stress (15).

So, this study revealed that the PGPR influenced the plant growth improvement under $\mathrm{Cd}$ stressed condition by different PGP traits. The observation in this study therefore supports the previous views as mentioned above.

Relative water content (Fig. 2) was drastically affected by $\mathrm{Cd}$ application comparing to control set. IAA treatment increased the RWC by 1.41 fold whereas; $L$. varians and $P$. putida enhanced 2.83 and 2.57 fold respectively than the only $\mathrm{Cd}$ treated plants. Vigour index was significantly $(p<0.05)$ (Fig. 3$)$ reduced with the $\mathrm{Cd}$ treatment by $48.63 \%$ than control setup. Whereas, increased VI was noticed in case of IAA application (1.81 fold) or PGPR inoculation under Cd stress. $L$. varians and $P$. putida appreciably boosted the VI by 1.28 and 2 fold accordingly than $\mathrm{Cd}$ amended condition alone.

Cd drastically reduced the chlorophyll content of mustard plant than the control plants (Fig. 4). Synthetic IAA application or PGPR inoculation enhanced the chlorophyll content significantly $(p<0.05)$ under $\mathrm{Cd}$ amended situation. $L$. varians and $P$. putida under $\mathrm{Cd}$ amended condition increased the total chlorophyll content respectively by 4.34 and 4.48 fold than Cd stressed alone. There was similar sterile soil condition, minimal position effects, same environmental condition, similar agronomic practices and randomised data sets collected from three triplicates of each treatment for this study. So, it can be apparently confirm that the growth enhancement under Cd stressed condition was due to the PGPRs. This PGPR mediated increment in the chlorophyll content was even better than the synthetic auxin application. These data coincided with the study of few others $(8,9,34)$. They examined that $\mathrm{Cd}$ reduces the chlorophyll content in wheat and rice respectively. Cd hampers the chlorophyll biosynthesis and reduces the amount of chlorophyll in green plants $(35,36)$. In this study rhizobacterial isolates positively increased the chlorophyll content under $\mathrm{Cd}$ stress condition which coincide the previous observations on different plants $(3,8,9,31)$. Pramanik et al. (2017) found that PGPR strain enhanced Chl-a, Chl-b and total chlorophyll content markedly ( $>2.5$ fold) in $\mathrm{Cd}$ amended condition than the control plants (31) which corroborate this work. The results in this 


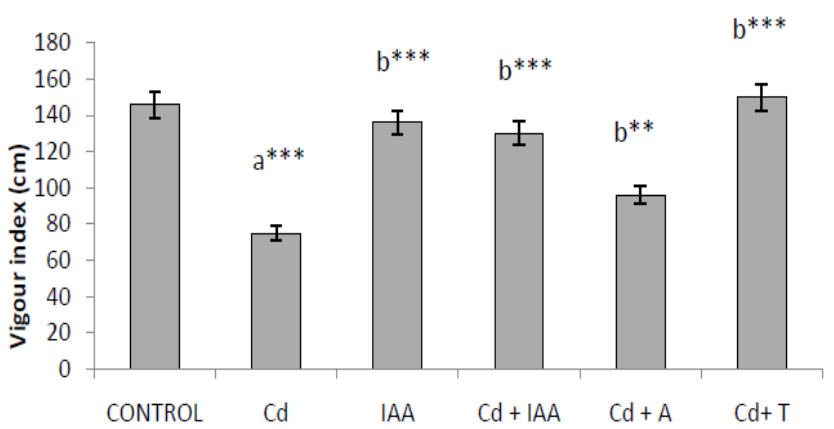

Fig. 3. Vigour index (cm) under Cd stress condition

Difference in between control and cadmium treated groups are denoted by lower case alphabet ' $a$ '. Whereas, lower case alphabet ' $b$ ' denotes the differences between $\mathrm{Cd}$ treated groups and respective other groups. Asterisk $(*)$ above the bars indicate significant level. (A- L. varians, $B$ - P. putida).

study showed that the growth improvement under $\mathrm{Cd}$ stressed condition was better than the exogenous synthetic IAA mediated growth.

\section{Conclusion}

Both the selected bacterial isolates, $L$. varians and $P$. putida having very promising PGP activities including IAA producing ability, showed growth promotion of mustard plants under cadmium stressed condition. This comparative analysis revealed that exogenous synthetic IAA application improved different growth parameters of Brassica plant to some extent in $\mathrm{Cd}$ amended condition. Moreover, very interesting results were obtained in case of PGPR application where $L$. varians and $P$. putida, ameliorated the $\mathrm{Cd}$ stress and showed various morphological improvement of mustard plants. In this observation it can be indicated that the application of IAA producing PGPR improved the vigor of mustard by reducing the deleterious effects of metal toxicity. Moreover PGPR mediated growth enhancement was better than the growth improvement by exogenous IAA application and even better than the unstressed control set. Hence, IAA producing $L$. varians and P. putida could be exploited for the sustainable agricultural development under Cd-contaminated soil.

\section{Author's contribution}

AKP conducted the whole experiment, collected the data, performed statistical analysis and written up the whole manuscript. SM supported the experimental works for different plant growth parameters. CS hypothesized the paper concept, designed the experiment, supervised throughout the process.

\section{Competing interests}

The authors declared that they have no competing interest.

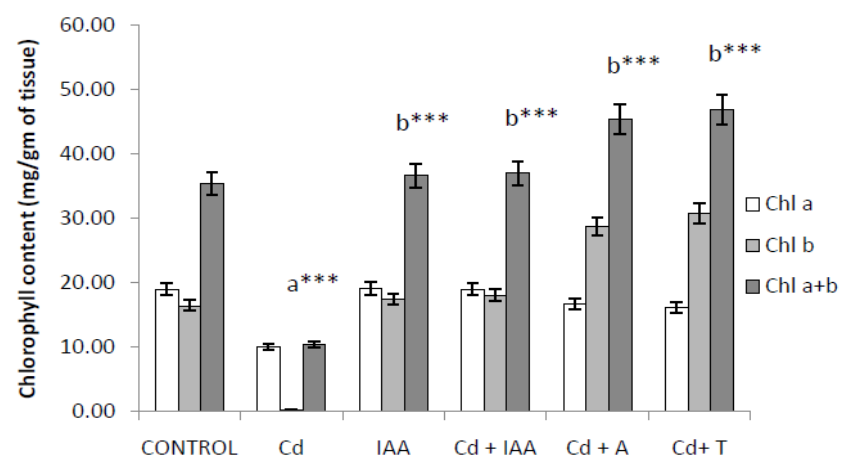

Fig. 4. Chlorophyll content (mg/gm tissue) under Cd stress condition (45 day)

Difference in between control and cadmium treated groups are denoted by lower case alphabet 'a'. Whereas, lower case alphabet ' $b$ ' denotes the differences between $\mathrm{Cd}$ treated groups and respective other groups. Asterisk (*) above the bars indicate significant level. (A- L. varians, B-P. putida).

\section{Acknowledgements}

The authors would like to acknowledge the financial help from DST-PURSE program to Department of Botany, University of Kalyani, from Department of Science and Technology, GOI, India.

\section{References}

1. Paroda RS, Malik SS. Rice genetic resources, its conservation and use in India. Oryza 1990;27(4):361-9.

2. Swaminathan MS. Enlarging the basis of food security: the role of underutilized species. In: International workshop held at the MS Swaminathan Research Foundation 1999 Feb 19 (pp. 17-19).

3. Zhang YF, He LY, Chen ZJ, Zhang WH, Wang QY, Qian M, Sheng XF. Characterization of leadresistant and ACC deaminase-producing endophytic bacteria and their potential in promoting lead accumulation of rape. Journal of hazardous materials 2011 Feb 28;186 (2-3):17205. https://doi.org/10.1016/j.jhazmat.2010.12.069

4. Kabata-Pendias A, Pendias H. Trace elements in soilsand plants, 3rd edn CRC Press. Boca Raton, FL, USA. 2001.

5. Singh UP, Sarma BK, Singh DP. Effect of plant growth-promoting rhizobacteria and culture filtrate of Sclerotium rolfsii on phenolic and salicylic acid contents in chickpea (Cicer arietinum). Current Microbiology 2003;46 (2):0131-40.

6. Krantev A, Yordanova R, Janda T, Szalai G, Popova L. Treatment with salicylic acid decreases the effect of cadmium on photosynthesis in maize plants. Journal of plant physiology 2008;165(9):920-31. https://doi.org/10.1016/j.jplph.2006.11.014

7. Popova LP, Maslenkova LT, Yordanova RY, Ivanova AP, Krantev AP, Szalai G, Janda T. Exogenous treatment with salicylic acid attenuates cadmium toxicity in pea seedlings. Plant Physiology and Biochemistry 
2009;47(3):224-31. https://doi.org/10.1016/j.plaphy.2008.11.007

8. Pal AK, Sengupta C. Effect of plant growth promoting rhizobacteria on early growth of Rice plant (Oryza sativa L.) under Cadmium (Cd) and Lead $(\mathrm{Pb})$ stress condition. International Journal of BioSciences \& Technology 2016;9(12).

9. Pal AK, Chakraborty A, Sengupta C. Differential effects of plant growth promoting rhizobacteria on chilli (Capsicum annuum L.) seedling under cadmium and lead stress. Plant Science Today 2018;5(4):1-9.

https://doi.org/10.14719/pst.2018.5.4.419

10. Yuan HM, Huang X. Inhibition of root meristem growth by cadmium involves nitric oxidemediated repression of auxin accumulation and signalling in Arabidopsis. Plant, cell \& environment 2016;39(1):120-35 . https://doi.org/10.1111/pce.12597

11. Li K, Kamiya T, Fujiwara T. Differential roles of PIN1 and PIN2 in root meristem maintenance under low-B conditions in Arabidopsis thaliana. Plant and Cell Physiology 2015;56(6):1205-14. https://doi.org/10.1093/pcp/pcv047

12. Yuan HM, Xu HH, Liu WC, Lu YT. Copper regulates primary root elongation through PIN1-mediated auxin redistribution. Plant and Cell Physiology 2013;54(5):766-78. https://doi.org/10.1093/pcp/pct030

13. Zelinová V, Alemayehu A, Bočová B, Huttová J, Tamás L. Cadmium-induced reactive oxygen species generation, changes in morphogenic responses and activity of some enzymes in barley root tip are regulated by auxin. Biologia 2015;70(3):356-64. https://doi.org/10.1515/biolog2015-0035

14. Besson-Bard A, Gravot A, Richaud P, Auroy P, Duc C, Gaymard F, Taconnat L, Renou JP, Pugin A, Wendehenne D. Nitric oxide contributes to cadmium toxicity in Arabidopsis by promoting cadmium accumulation in roots and by upregulating genes related to iron uptake. Plant Physiology 2009;149(3):1302-15. https://doi.org/10.1104/pp.108.133348

15. Farooq H, Asghar HN, Khan MY, Saleem M, Zahir ZA. Auxin-mediated growth of rice in cadmium-contaminated soil. Turkish Journal of Agriculture and Forestry 2015;39(2):272-6. https://doi.org/10.3906/tar-1405-54

16. Ahmad F, Ahmad I, Khan MS. Screening of freeliving rhizospheric bacteria for their multiple plant growth promoting activities. Microbiological research 2008;163(2):173-81. https://doi.org/10.1016/j.micres.2006.04.001

17. Gordon SA, Weber RP. Colorimetric estimation of indoleacetic acid. Plant physiology 1951;26(1):192. https://doi.org/10.1104/pp.26.1.192

18. Pikovskaya RI. Mobilization of phosphorus in soil in connection with vital activity of some microbial species. Mikrobiologiya 1948;17:36270.

19. Dye DW. The inadequacy of the usual determinative tests for the identification of
Xanthomonas spp. New Zealand Journal of Science 1962;5(4)

20. Bakker AW, Schippers B. Microbial cyanide production in the rhizosphere in relation to potato yield reduction and Pseudomonas sppmediated plant growth-stimulation. Soil Biology and Biochemistry 1987;19(4):451-7. https://doi.org/10.1016/0038-0717(87)90037-X

21. Jensen HL. Nitrogen fixation in leguminous plants. II. Is symbiotic nitrogen fixation influenced by Azotobacter. In: Proc. Linn. Soc. NSW 1942;67:205-212.

22. Schwyn B, Neilands JB. Universal chemical assay for the detection and determination of siderophores. Analytical biochemistry 1987;160(1):47-56. https://doi.org/10.1016/00032697(87)90612-9

23. Porra RJ, Thompson WA, Kriedemann PE. Determination of accurate extinction coefficients and simultaneous equations for assaying chlorophylls $\mathrm{a}$ and $\mathrm{b}$ extracted with four different solvents: verification of the concentration of chlorophyll standards by atomic absorption spectroscopy. Biochimica et Biophysica Acta (BBA). Bioenergetics 1989;975(3):384-94. https://doi.org/10.1016/S0005-2728(89)80347-0

24. Abdul-Baki AA, Anderson JD. Vigor determination in soybean seed by multiple criteria 1. Crop science 1973;13(6):630-3. https:// doi.org/10.2135/cropsci1973.0011183X00130006 $\underline{0013 x}$

25. Shah SS, Mohammad FI, Shafi M, BAKHT J, ZHOU W. Effects of cadmium and salinity on growth and photosynthesis parameters of Brassica species. Pakistan Journal of Botany 2011;43(1):333-40.

26. Aydinalp C, Marinova S. The effects of heavy metals on seed germination and plant growth on alfalfa plant (Medicago sativa). Bulgarian Journal of Agricultural Science 2009;15(4):34750.

27. Rajkumar M, Freitas H. Effects of inoculation of plant-growth promoting bacteria on Ni uptake by Indian mustard. Bioresource Technology 2008;99(9):3491-8.

https://doi.org/10.1016/j.biortech.2007.07.046

28. Kamran MA, Mufti R, Mubariz N, Syed JH, Bano A, Javed MT, Munis MF, Tan Z, Chaudhary HJ. The potential of the flora from different regions of Pakistan in phytoremediation: a review. Environmental Science and Pollution Research 2014;21(2):801-12. https://doi.org/10.1007/s11356-013-2187-7

29. Treesubsuntorn C, Dhurakit P, Khaksar G, Thiravetyan P. Effect of microorganisms on reducing cadmium uptake and toxicity in rice (Oryza sativa L.). Environmental Science and Pollution Research 2018;25(26):25690-701. https://doi.org/10.1007/s11356-017-9058-6

30. Belimov AA, Dietz KJ. Effect of associative bacteria on element composition of barley seedlings grown in solution culture at toxic cadmium concentrations. Microbiological 
research

2000;155(2):113-21. https://doi.org/10.1016/S0944-5013(00)80046-4

31. Pramanik K, Mitra S, Sarkar A, Soren T, Maiti TK. Characterization of cadmium-resistant Klebsiella pneumoniae MCC 3091 promoted rice seedling growth by alleviating phytotoxicity of cadmium. Environmental Science and Pollution Research 2017;24(31):24419-37. https://doi.org/10.1007/s11356-017-0033-Z

32. Pishchik VN, Vorobyev NI, Chernyaeva II, Timofeeva SV, Kozhemyakov AP, Alexeev YV, Lukin SM. Experimental and mathematical simulation of plant growth promoting rhizobacteria and plant interaction under cadmium stress. Plant and Soil 2002;243(2):17386. https://doi.org/10.1023/A:1019941525758

33. Abbass Z, Okon Y. Plant growth promotion by Azotobacter paspali in the rhizosphere. Soil Biology and Biochemistry 1993;25(8):1075-83. https://doi.org/10.1016/0038-0717(93)90156-6
34. Öncel I, Keleş Y, Üstün AS. Interactive effects of temperature and heavy metal stress on the growth and some biochemical compounds in wheat seedlings. Environmental pollution. 2000;107(3):315-20.

https://doi.org/10.1016/S0269-7491(99)00177-3

35. Somashekaraiah BV, Padmaja K, Prasad AR. Phytotoxicity of cadmium ions on germinating seedlings of mung bean (Phaseolus vulgaris): Involvement of lipid peroxides in chlorphyll degradation. Physiologia Plantarum 1992;85(1):85-9. https://doi.org/10.1034/j.13993054.1992.850113.x

36. Pätsikkä E, Kairavuo $M$, Šeršen F, Aro EM, Tyystjärvi E. Excess copper predisposes photosystem II to photoinhibition in vivo by outcompeting iron and causing decrease in leaf chlorophyll. Plant physiology 2002;129 (3):135967. https://doi.org/10.1104/pp.004788 